\title{
Enabling management control in improving the performance of SMEs
}

\author{
Tubagus Ismail ${ }^{a *}$, Meutia ${ }^{a}$ and Nurul Ummi ${ }^{a}$
}

${ }^{a}$ University of Sultan Ageng Tirtayasa, Indonesia Center of Exellence For Food Security, Jl. Raya Jakarta KM 4 Serang-Indonesia, 42118

\section{H R O N I C L E}

Article history:

Received: May 252019

Received in revised format: June

102019

Accepted: June 10, 2019

Available online:

June 10, 2019

Keywords:

Enbaling MCS

The Performance of SMES

Cost efficiency

Innovation

Creativity

\section{A B S T R A C T}

\begin{abstract}
This study aimed to investigate the effect of management control system enabling with capabilities that can improve the performance of SMEs. This study was conducted among the managers of SMEs of local food products in Banten Province, Indonesia. The number of respondents in this study was 85 SME managers. This study used structural equation modeling as an analytical tool and PLS Smart software to process the data. The findings of this study show that there was a positive effect of the use of enabling management control system (MCS) on creativity; there was a positive and significant effect of the use of Enabling MCS on cost efficiency; there was a positive and significant effect of the use of Enabling MCS on performance; there was a positive and significant effect of creativity on innovation; there was a positive and significant effect of cost efficiency on performance; and finally there was a positive and significant effect of innovation on performance. The implication of this study is that it can provide a choice of control system for SME management, which up to now still uses conventional control system. The use of Enabling MCS can create a capability for the managers of SMEs of local food products to win the competition. This is due to the uniqueness of Enabling MCS that can increase creativity and also cost efficiency.
\end{abstract}

\section{Introduction}

Small and Medium Enterprises (SMEs) are a manifestation of a people-driven economy, which is considered to have a strategic role and potential in mobilizing the National economy. However, the participation of the Indonesian people in the SME sector is still low. This is evidenced since only $24 \%$ of the population involved in Indonesia. In fact, in order for the Indonesian economy to grow faster, more people are needed to be involved in SMEs. Entrepreneurs are presently work for large, medium and small businesses. The number of SMEs in Indonesia is still low compared with neighboring countries such as Malaysia and Singapore (Sudaryanto et al., 2016). In addition, the development of SMEs in Indonesia faces various constraints including lack of quality resources, product marketing, raw materials and capital (Meutia, 2017). These constraints have resulted in the less optimal competitiveness and the performance of SMEs.

One way to improve the performance of SMEs is to improve the capabilities of SMEs through appropriate strategies such cost reduction. SMEs must achieve competitive advantages in order to survive in the current business environment characterized by fast consumer changes, sophisticated technology and tough 
business competition (Porter, 1983). A study conducted by Henri (2006) reveals that capability was the main attribute for improving performance. Capabilities that can improve the performance of SMEs are creativity and innovation (Ismail, 2016). Creativity and innovation are recognized as the main capabilities which could may contribute significantly to the performance of the firms (Cefis \& Marsili, 2006; Matolcsy $\&$ Wyatt, 2008). Creativity is closely related to the development of useful new ideas, while innovation is associated with the success of the developing new ideas (West \& Farr, 1990). Therefore, creativity will be the initial stage of innovation. Product innovation has been recognized as the development tool and life of an organization (Cefis \& Marsili, 2006; Matolcsy \& Wyatt, 2008). However, the role of innovation, creativity and strategy will not be optimal without the support and role of good management control system (MCS) (Ismail \& Ghozali, 2015).

MCS is a tool used by managers to achieve firms' objectives through controlling the available resources (Ismail, 2016). MCS is a process by which managers ensure the resources they use are effective and efficient in achieving organizational objectives (Chapman, 1998; Anthony \& Govindarajan, 2004; Davila, 2005). The resources used in this study were creativity, innovation and cost efficiency. Creativity is closely associated with the development of useful new ideas, while innovation is the success of the development of a new idea. Various studies have been conducted in the management accounting literature that observed the contribution of MCS in improving organizational creativity (Simons, 1991, 1995; Davila et al., 2009), but the effect of knowledge on how MCS influences creativity is still limited (Davila et al., 2009). Therefore a study to examine the relationship between MCS and organizational creativity improvement is needed (Simons, 1991, 1995; Davila et al., 2009). According to Simons (1995) MCS is a formal process, based on routine information and procedures used by managers to maintain or change the patterns of organizational activity. MCS includes management accounting system, budget practices, performance measurement system, project management system, planning system and reporting systems (Simons, 1990). The purpose of MCS is to provide information that is useful for managerial in decision making, planning, monitoring and evaluating organizational activities by changing the employees' behavior (Merchant \& Van der Stede, 2007). MCS also provides direction for innovative and efficient strategic efforts with limited resources. MCS helps top managers formulate strategies, determine operational actions, implement strategies, clarify expectations, identify priorities for operational improvement, and set targets and improve performance (Simons, 1995). Only a few of the previous studies that observed how MCS was used for the SMEs (Acquaah, 2013; Ismail, 2016), even though around $90 \%$ of all businesses around the world were included in the SME sector (Acquaah, 2013). The results of the study conducted by Acquaah (2013) found that dynamic MCS could increase cost efficiency in the SME industry in Ghana. Enabling MCS was used in this study (Radtke \& Widener, 2016). The use of Enabling MCS is a control used by the managers to guide, direct, motivate, evaluate employee behavior and performance. The use of Enabling MCS will increase creativity, find new products, and work efficiently (Jorgensen and Messner, 2009).

\section{Literature Review and Development of Hypotheses}

\subsection{Effect of MCS Enabling on creativity and cost efficiency}

The use of Enabling MCS was first developed by Adler and Borys (1966), which allows employees to share information, be involved, and to understand, think about, improve and perform their functions better. It's potential benefits include empowerment, autonomy (independent) and involvement (Adler \& Borrys 1966). Wouters and Wilderom (2008) conducted a study in the logistics department of beverage manufacturing companies and concluded that Enabling MCS could improve skills, competencies, experience, professional attitudes and creativity. Jorgensen and Messner (2009) found that using Enabling MCS could enable organizations to work in efficiency and flexibility better. Jorgensen and Messner (2009) described that the use of Enabling MCS in developing new products would provide benefits, because employees would make continuous improvements. Jorgensen and Messner (2009) found that managers did not regard 
performance measures as a problem because their performance measurement was flexible. The use of Enabling MCS enables the companies to harmonize activities with company strategies, the end result can create creativity, tacit knowledge, new knowledge. Employees who are controlled by enabling MCS will then be able to understand the company's strategy well and prioritize companies to achieve goals. An open environment makes employees to be able to share knowledge and insights. The use of Enabling MCS can also have a negative impact, for example, employees are not given penalties when they behave that only benefits themselves, since in enabling MCS, non-fulfillment of performance is not a problem (Jordan \& Mesner, 2012). The use of Enabling MCS is characterized by a high level of trust. Formally this study develops the following hypothesis:

$\mathrm{H}_{1}$ : The use of Enabling MCS has a positive effect on creativity.

Hz: The use of Enabling MCS has a positive effect on cost efficiency.

\subsection{The effect of the use of Enabling MCS on the performance of SME}

The function of MCS is to provide information that is useful in decision making, planning and evaluation (Merchant \& Otley, 2006). MCS controls the decision making by guiding desired organizational behavior to achieve company goals (Bhimani et al., 2009). MCS consists of various control systems that are interrelated and complementary to achieve competitive advantage (Henri, 2006). Kallunki et al. (2011) examined the effect of formal MCS and informal MCS in implementing entrepreneurial resource planning (ERP). Kallunki's study 70 recruited chief financial officers from business units in the manufacturing industries in Indonesia as the respondents. The results found that the use of formal MCS and informal MCS in addition had a positive effect on ERP implementation and also had a positive effect on financial performance and non-financial performance. Enabling MCS is used to safeguard organizational members from unwanted behavior. Resistance to unwanted behavior will affect competitive advantages (Henri \& Journeault, 2010). Competitive advantages obtained can be in the form of cost efficiency of material, process and production (Henri \& Journeault, 2010). MCS could improve performance by making improvements to accounting information (Kallunki et al., 2011). Adequate accounting information could effectively manage resources and contribute on improving competitive advantage (Grafton et al., 2010). MCS encourages alignment between business strategy, environment and organizational value (Grafton et al., 2010). Furthermore MCS allowed managers to (i) do adjustments to strategies when the results were not as expected, (ii) improve communication to achieve expected goals, (iii) motivate performance based on organizational values, (iv) encourage managers directly pay special attention on critical success factors, (v) provide a deeper understanding of goals, actions and results (Henri \& Journeault, 2010). MCS could ultimately improve competitive advantage (Henri \& Journeault, 2010). This is in accordance with the RBV's point of view that the resources owned by the company must be managed properly by MCS (Henri, 2006). It is formally stated in the following hypothesis:

$\mathrm{H}_{3}$ : The use of Enabling MCS has a positive effect on the performance of SMEs.

\subsection{Effect of creativity on innovation}

Creativity is the actualization of potentials, including integrity from the logical side and continuity side (Young, 1985). This not only improves thought but also maintains relationship with the past. Fillis and Rentschler (2006) considered creativity as something that can be imagined and is not a non-routine thing while also building traditions to get favorable results. Creativity is something that arises from interactions between individuals and situations, facilitated by the appropriate environment and climate (Hunter et al., 2007). A product is not only the outcome of intangible assets, but also influenced by creative processes and creative capabilities involved in the production process (Magyari-Beck, 1990). Innovation as a commercial tangibilization of creativity is more often known as the driving force behind the success of business conduct and should be seen as an investment rather than an undesirable cost (Kuczmarski, 1996). The difference between creativity and innovation is that creativity is seen as the production of new ideas which 
can be useful in any field. Innovation is seen as a successful implementation of creative ideas within organizations (Ismail, 2016).

Creativity describes imaginative ideas (Amabile, 1996), while innovation requires successful applications (Tidd \& Bessant, 2009). Innovation is the process of developing and bringing creative ideas into finished products so that the products can be utilized and marketed (Ismail, 2016). The process that describes the conversion of discovery into another business or useful application is defined as exploitation (Roberts, 2007) or conversion ability (Chand, 2006). Innovation is a process through which entrepreneurs convert through workable, profitable market opportunities and valuable ideas. This process is in accordance with the point of view of RBV. Successful innovation is something valuable, rare, inimitable and irreplaceable with other products (Barney, 1991). Innovation is the application of something creative that has a significant impact on an organization, industry and society. Entrepreneurship is the next generation of innovation in response to opportunities recognized in the business environment. Based on this description, this study proposes the following hypothesis:

H4: Creativity has a positive effect on innovation.

\subsection{Effect of cost efficiency on the performance of SMEs}

During the 2007 crisis, many companies cut their operational costs and reduced their research and development budget (Birjandi et al., 2014). To survive in the crisis circumstances the companies allocated resources efficiently (Valipour et al., 2012) and looked for cheaper suppliers (Christopher, 2011). The ability to see "a light at the end of the tunnel" during a financial crisis is a very important part. One of the keys to successful strategy implementation in the era of crisis and booming is the implementation of strategies followed by efficiency (Ismail \& Ghozali, 2015). Therefore many companies made improvements to activities that could reduce their costs (Almeida et al., 2015). Companies did many improvement strategies to improve the company's competitive position (Lee et al., 2016). Companies that win competition in the financial recession were those that carried out marketing strategies accompanied by competitive advantage activities (Pearce \& Michael, 1997). The intensive marketing strategies (e.g. cost efficiency) would enhance competitive advantage and company performance (Valipour et al., 2012). Cost efficiency (employees, energy and materials) had a positive effect on company performance in the time of crisis (Kukanja \& Planinc, 2013). The recent empirical study of companies listed in the Tehran Security Exchange showed that there was a positive and significant effect of the current cost reduction on financial performance in the future (Birjandi et al., 2014). Based on this description, this study proposes the following hypothesis:

$\mathrm{H}_{5}$ : Cost Efficiency has a positive effect on the performance of SMEs.

\subsection{Effect of innovation on the performance of SMES}

It has been widely recognized by researchers that innovation is the main source for winning business competition (Schumpeter, 1934), including in the SME industry. Study on innovation generally focused on two main issues: (1) antecedent of innovation and (2) the effect of innovation on business performance (Christopher et al., 2012). Most studies on innovation focused on large companies, which had a significant impact on the budget of the research and development (R\&D) center. It is still unclear whether understanding of innovations taken from studies on large companies can be applied in SMEs. SMEs tend to focus on additional innovation rather than basic innovation (Oldham \& Chummings, 1996). Innovation in SMEs is an active response to their main competitors by adopting new ways of doing things (such as innovations in processes) (Wang, 2009). SMEs which had a desire to use new ways of doing things, tried unusual ways, solved problems in new ways, and encouraged employees to think and work differently had higher performance than their competitors (Saunders et al., 2014). SMEs with high levels of innovation would get high performance (Wang, 2009). In a study of 159 SMEs, Hyvonen and Tuominen (2006) showed that the discovery of technological innovation capabilities and strong relationships with consumers and supply 
chain partners were determinants of the achievements of economic success. Innovation as a commercialization of creativity, is more often known as the driving force behind the success of business conduct and should be seen as an investment rather than undesirable cost (Kuczmarski, 1996). Innovation has been recognized as the main capability of achieving competitive advantage, to fulfill and create markets (Henri, 2006). Innovation refers to the company's openness to new ideas, new products and new processes (Hurley \& Hult, 1998). Innovation is a capability that is valuable, inimitable and irreplaceable (Henri, 2006). Innovation has been considered by researchers as a critical factor for companies to win business competition effectively (Hitt et al., 2001). Companies that had a higher capacity to create innovations would have higher performance than their competitors (Danneels, 2002). Based on this description, this study proposes the following hypothesis:

H6: Innovation has a positive effect on the performance of SMEs

The following figure shows the study model:

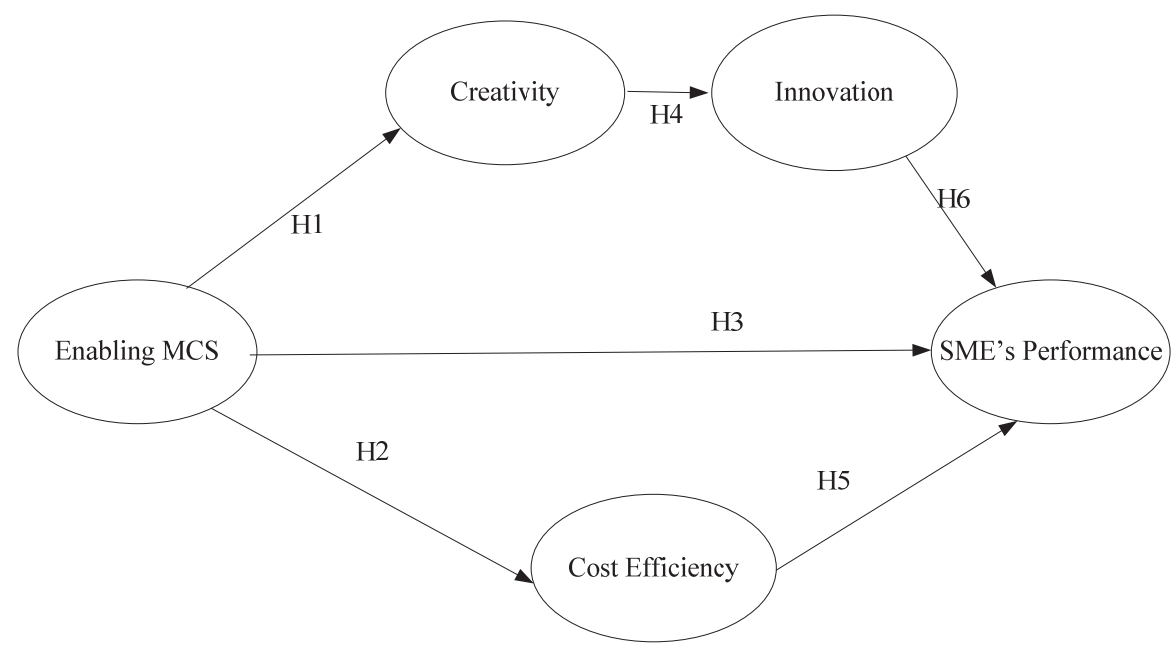

\section{Methods}

Fig. 1. Research Model

The study sampling was conducted using a purposive sampling method on 85 SME managers in Banten by giving questionnaires to SME leaders directly. In this study, the researchers took samples with the following criteria: 1. Managing SMEs in Banten in the field of local food processing industries; 2. Have already been managing SMEs for at least 2 years.

\subsection{Variable Measurement}

The measurement indicators of Enabling MCS were developed from seven indicators derived from modified Radke and Widener's theory (2016), namely: (1) Work on everything efficiently, to produce the best goods or services. (2) Managing a business must always be better than the past, and future business performance must be carried out far better. (3) Business management must be based on the principle of volunteerism and mutual trust, (4) Continually improves the production process, (5) The company is very open to input from staff, consumers and suppliers, (6) Measurement/assessment system that is adapted to the ability of each employee (flexible), (7) Employees are given independence in doing work, with the principle of mutual trust in maintaining honest behavior and keeping the mandate. Creativity was measured by indicators originated from Ismail (2016) with five questions; namely: creative in building new ideas, (2) comfortable environment (3) utilizing time, (4) always considering new ways (5) the frequency of new ideas. The cost efficiency was measured by six questions derived from the work of Valipour et al. (2012), namely: operating efficiency, price, managing raw materials, efficient promotion, 
touching the production process, reducing product costs. The indicators for measuring innovation were developed from the work of Henri (2006) with three questions; namely: appreciation of employees for new ideas, overall active participation of employees, the failure of innovation is not considered as a risk. The performance of SMEs was measured by four questions (Stam \& Elfring, 2008); namely: sales growth, market share, employee development and profit. This study used the Partial Least Square statistical tool. The results of PLS inner weight were as follows:

Table 1

Results of Inner Weights

\begin{tabular}{lccccc}
\hline & $\begin{array}{c}\text { Original } \\
\text { Sample (O) }\end{array}$ & $\begin{array}{c}\text { Sample Mean } \\
(\mathrm{M})\end{array}$ & $\begin{array}{c}\text { Standard Deviation } \\
(\text { STDEV })\end{array}$ & $\begin{array}{c}\text { T Statistics } \\
(|\mathrm{O} / \mathrm{STERR}|)\end{array}$ & Hipotesis \\
\hline MCS enabling $\rightarrow$ creativity & 0,967 & 0,9667 & 0,007 & 134,681 & Supported \\
MCS enabling $\rightarrow$ Cost efficiency & 0,940 & 0,939 & 0,012 & 72,517 & Supported \\
MCS enabling $\rightarrow$ SME's Performance & 0,593 & 0,590 & 0,088 & 6,721 & Supported \\
Creativity $\rightarrow$ Innovation & 0,936 & 0,935 & 0,014 & 66,854 & Supported \\
Cost efficiency $\rightarrow$ SME's Performance & 0,183 & 0,183 & 0,055 & 3,332 & Supported \\
Innovation $\rightarrow$ SME's performance & 0,204 & 0,206 & 0,066 & 3,059 & Supported \\
\hline
\end{tabular}

From Table 1 above, it can be seen that the use of Enabling MCS had a positive effect of 0.967 and was significant at 0.05 (134.681>1.96) on creativity. The use of Enabling MCS had a positive effect of 0.940 and was significant at $0.05(72.517>1.96)$ on cost efficiency. The path coefficient value on the relationship between the use of Enabling MCS and the performance of SMEs was 0.593 and significant at $0.05(6.721>1.96)$ so that it can be concluded that the use of Enabling MCS had a positive and significant effect on the performance of SMEs. In addition, the creativity variable also had a positive and significant effect on the innovation variable. This is evidenced by the path coefficient value of 0.936 and $\mathrm{t}$ statistics of $66.854>1.96$. On the other hand, the construct of cost efficiency had a positive effect on the performance of SMEs with path coefficient value of 0.183 and was significant at $0.05(3.332>1.96)$. Meanwhile, innovation construct had a path coefficient value of 0.204 and was significant at $0.05(3,059>$ 1.96). So, it can be concluded that innovation had a positive effect on the performance of SMEs.

Enabling MCS had a positive effect on creativity. The more optimal implementation of the use of SPM enables more creativity of SMEs. The use of Enabling MCS allows employees to share information, get involved, and to understand, think about, improve and perform their functions better. The results of the study illustrated that the use of Enabling MCS could monitor and encourage creativity as a capability in winning competition. Creativity which is part of the company's unique resources is a form of capability that brings competitive advantage. This is in line with the approach of resource based theory (RBV) which states that resources can provide more economic advantage to owners with limited availability of resources. Resources and capabilities are an inseparable bond. This finally explains that the RBV considers the company as a bond and shows that these attributes have a significant effect on the company's competitive advantage and will have an impact on the company's performance (Barney, 1991; Lee et al., 2001). The findings of this study support the study conducted by Henri (2006); Grafton et al. (2010) and Ismail (2016) who found that MCS had a positive effect on creativity. Based on these empirical findings, the first hypothesis in this study was accepted. The second finding of this study was that the use of Enabling MCS had a positive effect on cost efficiency. The relationship formed between the constructs of the use of SPM enabling and cost efficiency was a causal relationship. After making efficiency in work, an indication of the Enabling MCS implementation in SMEs was known from strict control of unnecessary costs. Elimination of unnecessary costs will reduce production costs so that the selling price of the product can increase. The study results described that the use of Enabling MCS was able to facilitate and adjust the strategies chosen by the organization, the results of this study significantly support contingency theory which states that companies must basically adapt to various contextual factors. Contingency theory by Bisbe and Otley (2004) states that MCS needs to be adapted to the organization's strategy. The result of the empirical test on the second hypothesis is in line with the study conducted by Aquaach (2013) which 
revealed that SPM affected the cost efficiency. In addition, strict control of costs is part of the company's strategy to win competition (Ismail \& Ghozali, 2016).

The third finding show that the use of Enabling MCS had a positive effect on the performance of SMEs. Based on the calculation result on the parameter coefficient between the use of Enabling MCS and the SMEs performance it was found that there was a positive effect of 0.590 with a t-statistic value of 6.721 and significant at 0.05 . The $t$-statistic value was greater than the critical value of \pm 1.96 with a significance level above the 0.05 , thus, it can be concluded that the third hypothesis was accepted. The use of Enabling MCS could increase the performance, noble values are a form of control over the behavior of SME actors. This is evidenced by the indicator of prioritizing people rather than personal without neglecting personal needs, SME managers had the main motivation to improve the performance of SMEs they managed. The study result is in line with the study conducted by Simons (2000) who found that levers of control (beliefs, boundary, diagnostic and interactive systems) worked together to improve performance (Widener, 2007). In addition, it is also in line with the study conducted by Kallunki et al. (2011) who examined the effect of formal MCS and informal MCS in applying entrepreneurial resource planning (ERP). The fourth study finding was that creativity had a positive effect on innovation, the ability to develop new ideas and new ways to solve problems in the face of opportunities. Henri (2006) reveals that creativity is a company's capability to achieve competitive advantage. The construct of creativity is formed by five indicators, namely: (1) The company encourages everyone in the company to act creatively, (2) The company provides a comfortable environment to produce useful new ideas, (3) Always use time to generate new useful ideas in work, (4) Always consider the use of new ways in work, (5) The frequency of applying new ideas is arranged so that they would not overlap. This finding explains that creativity is a matter that arises from interactions between individuals and situations, facilitated by the appropriate environment and climate (Hunter et al., 2007). The difference between creativity and innovation in creativity is seen as the production of useful new ideas in any field. Innovation is seen as a successful implementation of creative ideas in organizations (Ismail, 2016). The result of this study is in line with the finding of a study conducted by Ismail (2016) which found that creativity had a positive effect on innovation. Based on the above description, creativity describes imaginative ideas (Amabile et al., 1996). Meanwhile, innovation requires successful applications (Tidd \& Bessant, 2009). Creativity is the root of innovation so it encourages companies to survive and has a competitive advantage in winning complex business competition. The above description provides sufficient evidence to accept the fourth hypothesis in this study. The result of the fifth hypothesis found that cost efficiency had a positive effect on the performance of SMEs. Innovation is the company's openness to new ideas, new products and new processes.

One indication of innovation in SMEs could be seen from the appreciation given by the companies to employees for their useful new ideas. The biggest innovation construct indicator was that companies gave appreciation to employees for their useful new ideas. In addition, innovation presence in SME organizations was supported by the active role of all organizational members in finding creative ideas that had an impact on the intensity of innovations. On the other hand, the development of innovation in SMEs of local food products was supported by SME leaders. This support was in the form of embedding the value that failure in innovation was not a risk but an investment for business progress. Empirical data showed that companies did not consider innovation as something risky as an indicator of the third largest innovation construct. This illustrated that the high growth of innovation in SMEs was due to the support of leaders who viewed that failure was not a risk. Thus, the intensity of the innovation presence became high since the fear of failure was low because failure was not considered a risk to encourage innovation as much as possible. The leadership presumption that failure of innovation was not a risk could encourage the staffs and create a climate of innovation that drove sustainable innovation within the organization. Innovation is a scarce resource and varies between business entities. Innovation is the capability of SME entities to achieve competitive advantage. This is in line with the resource base view approach which assumes that a business entity must have resources as the capabilities to achieve competitive advantage. The study result found that innovation had been recognized as the main capability of achieving competitive advantage to fulfill and create markets (Henri, 2006). Innovation refers to the 
company's openness to new ideas, new products and new processes (Hurley \& Hult, 1998). Innovation is a capability that is valuable, inimitable and irreplaceable (Henri, 2006). Innovation has been considered by the researchers as a critical factor for companies to win effective business competition (Hitt et al., 2001). Companies with a higher capacity to create innovations will have higher performance than their competitors (Danneels, 2002). The study result is also in line with the study conducted by Ismail (2015) who found that innovation had a positive effect on the performance of the creative industry. The sixth finding in this study show that cost efficiency had a positive effect on the performance of SMEs. The better the implementation of cost efficiency, the higher the performance of SMEs. The result of the sixth hypothesis test in this study also found that cost efficiency had a significant effect on the performance of SMEs. Cost efficiency is a series of integrated actions taken to produce goods or services with unique features to sell to customers at the lowest cost compared with competitors. SMEs sorted the costs needed in the production process of their products. Sorting these costs aimed to produce products that had low production costs while maintaining product quality. The study result is in line with the study conducted by Power and Han (2004) which stated that cost efficiency had a significant effect on performance. The same thing was also stated by Allens and Helm (2006) who found that cost efficiency was correlated with performance.

\section{Conclusions and Implications}

The model developed in this study was more influenced by the contingency theory approach and the RBV theory. The use of Enabling MCS would encourage strategies chosen by the organization. The strategies used in SMEs were resource-based strategies (cost efficiency, creativity and innovation). The use of Enabling MCS had unique advantages, in this study enabling control could not only increase creativity but also made efficiency. Enabling control could increase the capabilities of SMEs namely valuable, rare, inimitable and irreplaceable to achieve competitive advantage. The study conducted by Henri (2006) stated that creativity and innovation were capabilities owned by the company to achieve competitive advantage. The use of MCS enabling, creativity and innovation were the capabilities possessed by SMEs of local food products in Banten province which were used in improving performance and achieving competitive advantage. The model developed in this study was in accordance with the contingency theory and the RBV theory. On the other hand, with a low selling price due to cost efficiency, it is expected that sales rate will rise and rapid consumer growth can be achieved so that organizational performance will be high. This study may contribute to the field of management accounting through several ways. First, this study framework provides new insights into the implementation of MCS and strategies. Second, many previous studies that examined MCS and strategies were still ambiguous and even contradictory. One of the reasons was the lack of an Enabling MCS framework. This study developed MCS enabling. Third, this study contributes to the results of the empirical work proposed by Radtke and Widener (2016), the results support the view that the use of enabling control could improve capabilities. On the other hand a study conducted by Radtke and Widener (2016) examined the use of enabling control with qualitative method. Meanwhile, this study used enabling control with quantitative method.

\section{References}

Acquaah, M. (2013). Management control systems, business strategy and performance: A comparative analysis of family and non-family businesses in a transition economy in sub-Saharan Africa. Journal of Family Business Strategy, 4(2), 131-146.

Adler, P. \& Borys, B. (1996). Two types of bureaucracy: Enabling and coercive. Administrative Science Quarterly, 41(1), 61-89

Alonso-Almeida, M. D. M., Bremser, K., \& Llach, J. (2015). Proactive and reactive strategies deployed by restaurants in times of crisis: Effects on capabilities, organization and competitive advantage. International Journal of Contemporary Hospitality Management, 27(7), 1641-1661.

Barney, J. (1991). Firm resources and sustained competitive advantage. Journal of Management, 17(1), 99-120. 
Bhimani, A., Gulamhussen, M. A., \& Lopes, S. (2009). The effectiveness of the auditor's going-concern evaluation as an external governance mechanism: Evidence from loan defaults. The International Journal of Accounting, 44(3), 239-255.

Birjandi, H., Jahromi, N. M., Darabi, S. A., \& Birjandi, M. (2014). The effect of cost leadership strategy on ROA and future performance of accepted companies in Tehran Stock Exchange. Research Journal of Finance and Accounting, 5(7), 152-159.

Bisbe, J., \& Otley, D. (2004). The effects of the interactive use of management control systems on product innovation. Accounting, Organizations and Society, 29(8), 709-737.

Cefis, E., \& Marsili, O. (2006). Survivor: The role of innovation in firms' survival. Research Policy, 35(5), 626-641.

Chan, D. (2006). Interactive effects of situational judgment effectiveness and proactive personality on work perceptions and work outcomes. Journal of Applied Psychology, 91(2), 475.

Chapman, C. S. (1998). Accountants in organisational networks. Accounting, Organizations and Society, 23(8), 737-766.

Christopher, M. (2011). Logistics \& Supply Chain Management $4^{\text {th }}$ ed. Great Britain: Pearson Education.

Danneels, E. (2002). The dynamics of product innovation and firm competences. Strategic Management Journal, 23, 1095-1121.

Davila, A., Foster, G., \& Oyon, D. (2009). Accounting and control, entrepreneurship and innovation: Venturing into new research opportunities. European Accounting Review, 18(2), 281-311.

Davila, T. (2005). An exploratory study on the emergence of management control systems: formalizing human resources in small growing firms. Accounting, Organizations and Society, 30(3), 223-248.

Fillis, I., \& Rentschler, R. (2006). Creative Marketing: An Extended Metaphor for Marketing in a New Age. Palgrave Macmillan, Basingstoke.

Grafton, J., Lillis, A. M., \& Widener, S. K. (2010). The role of performance measurement and evaluation in building organizational capabilities and performance. Accounting, Organizations and Society, 35(7), 689-706.

Henri, J. F., \& Journeault, M. (2010). Eco-control: The influence of management control systems on environmental and economic performance. Accounting, Organizations and Society, 35(1), 63-80.

Henri, J. F. (2006). Management control systems and strategy: A resource-based perspective. Accounting, organizations and society, 31(6), 529-558.

Hitt, M. A., Ireland, R. D., Camp, S. M., \& Sexton, D. L. (2001). Strategic entrepreneurship: Entrepreneurial strategies for wealth creation. Strategic management journal, 22(6-7), 479-491.

Hunter, S. T., Bedell, K. E., \& Mumford, M. D. (2007). Climate for creativity: A quantitative review. Creativity research journal, 19(1), 69-90.

Hurley, R. F., \& Hult, G. T. M. (1998). Innovation, market orientation, and organizational learning: an integration and empirical examination. Journal of Marketing, 62(3), 42-54.

Hyvonen, S., \& Tuominen, M. (2006). Entrepreneurial innovations, market-driven intangibles and learning orientation: critical indicators for performance advantages in SMEs. International Journal of Management and Decision Making, 7(6), 643-660.

Ismail, T. (2016). Culture control, capability and performance: evidence from creative industries in Indonesia. Asian Review of Accounting, 24(2), 171-184.

Ismail, T., \& Ghozali, I. (2015). Control system, strategy and learning. Academy of Strategic Management Journal, 14(1), 58.

Jordan, S., \& Messner, M. (2012). Enabling control and the problem of incomplete performance indicators. Accounting, Organizations and Society, 37(8), 544-564.

Jørgensen, B., \& Messner, M. (2009). Management control in new product development: The dynamics of managing flexibility and efficiency. Journal of Management Accounting Research, 21(1), 99-124.

Kallunki, J. P., Laitinen, E. K., \& Silvola, H. (2011). Impact of enterprise resource planning systems on management control systems and firm performance. International Journal of Accounting Information Systems, 12(1), 20-39. 
Kuczmarski, T.D. (1996). Fostering an Innovation Mindset. Journal of Consumer Marketing, 13(6), 7-13.

Kukanja, M., \& Planinc, T. (2013). The response of the restaurant industry to the financial crisis. Ekonomska misao i praksa, (1), 39-56.

Lee, V. H., Foo, A. T. L., Leong, L. Y., \& Ooi, K. B. (2016). Can competitive advantage be achieved through knowledge management? A case study on SMEs. Expert Systems with Applications, 65, 136151.

Magyari-Beck, I. (1986, September). The main paradigms in social sciences. In Cheiron Europe. V. International Conference. Varna.

Matolcsy, Z. P., \& Wyatt, A. (2008). The association between technological conditions and the market value of equity. The Accounting Review, 83(2), 479-518.

Meutia, M. (2017). Proactive Attitude and Organizational Performance. International Journal of Economic Perspectives, 11(1).

Oldham, G. R., \& Cummings, A. (1996). Employee creativity: Personal and contextual factors at work. Academy of management journal, 39(3), 607-634.

Pearce II, J. A., \& Michael, S. C. (1997). Marketing strategies that make entrepreneurial firms recessionresistant. Journal of Business Venturing, 12(4), 301-314.

Porter, M. E. (1980). Competitive Strategy: Techniques for Analyzing Industries and Competitors. New York: Free Press.

Radtke, R. R., \& Widener, S. K. (2016). The Complex World of Control: Integration of Ethics and Uses of Control. In Performance Measurement and Management Control: Contemporary Issues (pp. 17-38). Emerald Group Publishing Limited.

Roberts, E. B. (2007). Managing invention and innovation. Research-Technology Management, 50(1), 3554.

Saunders, M. N., Gray, D. E., \& Goregaokar, H. (2014). SME innovation and learning: the role of networks and crisis events. European Journal of Training and Development, 38(1/2), 136-149.

Schumpeter, J. (1934). The theory of economic development Harvard University Press. Cambridge, MA.

Simons, R. (1990). The role of management control systems in creating competitive advantage: new perspectives. Accounting, Organizations and Society, 15(1-2), 127-143.

Simons, R. (1991). Strategic orientation and top management attention to control systems. Strategic management journal, 12(1), 49-62.

Simons, R. (1995). Levers of control: How managers use innovative control systems to drive strategic renewal. Boston: Harvard Business School Press.

Stam, W., \& Elfring, T. (2008). Entrepreneurial orientation and new venture performance: The moderating role of intra-and extraindustry social capital. Academy of management journal, 51(1), 97-111.

Sudaryanto, Ragimun dan Wijayanti, Rahma Rina. (2016). SME's Strategy forward Free Trade Market.//www.kemenkeu.go.id/sites/default/files/strategi\%20pemberdayaa 20UMKM

Tidd, J., \& Bessant, J. (2009), Managing Innovation: Integrating Technological, Market And Organizational Change. 4th ed., John Wiley \& Sons Ltd, West Sussex.

Valipour, H., Birjandi, H., \& Honarbakhsh, S. (2012). The effects of cost leadership strategy and product differentiation strategy on the performance of firms. Journal of Asian Business Strategy, 2(1), 14.

Farr, J. L., \& West, M. A. (Eds.). (1990). Innovation and creativity at work: Psychological and organizational strategies. Wiley.

Wouters, M., \& Wilderom, C. (2008). Developing performance-measurement systems as enabling formalization: A longitudinal field study of a logistics department. Accounting, Organizations and Society, 33(4-5), 488-516.

Young, J.G. (1985). What is creativity? Journal of Creative Behavior, 19(2), 77-85.

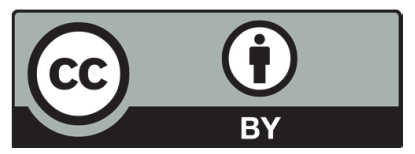

C 2019 by the authors; licensee Growing Science, Canada. This is an open access article distributed under the terms and conditions of the Creative Commons Attribution (CCBY) license (http://creativecommons.org/licenses/by/4.0/). 